\title{
Analysis of Gasoline Used by Motorbike-Taxi Drivers in Cotonou
}

\author{
Boris Cachon ${ }^{1,2,3}$, Lucie Ayi-Fanou ${ }^{3}$, Fabrice Cazier ${ }^{1,4}$, Paul Genevray ${ }^{4}$, Kifouli Adéoti ${ }^{3}$, Dorothee Dewaele ${ }^{1,4}$, \\ Agnes Debende ${ }^{1,4}$, Faustin Aissi ${ }^{1} \&$ Ambaliou Sanni ${ }^{3}$ \\ ${ }^{1}$ Université Lille Nord de France, Lille, France \\ ${ }^{2}$ Unité de Chimie Environnementale et Interactions sur le Vivant (UCEIV) EA 4492, Maison de la Recherche en \\ Environnement Industriel 2, Université du Littoral-Côte d'Opale, Dunkerque, France \\ 3 Laboratoire de Biochimie et Biologie Moléculaire, Faculté des Sciences et Techniques, Université \\ d'Abomey-Calavi, Cotonou, Bénin \\ ${ }^{4}$ Centre Commun de Mesures, Maison de la Recherche en Environnement Industriel 1, Université du Littoral-Côte \\ d'Opale, Dunkerque, France
}

Correspondence: Ambaliou Sanni, Faculté des Sciences et Techniques, Université d'Abomey-Calavi, Cotonou 04 BP 0320, Bénin. Tel: 229-21-30-1024. E-mail: ambaliou.sanni@gmail.com

Received: December 24, 2012 Accepted: February 4, 2013 Online Published: March 12, 2013

doi:10.5539/ep.v2n2p39 URL: http://dx.doi.org/10.5539/ep.v2n2p39

\begin{abstract}
In 2009, samples from itinerant stations were taken in Cotonou. Official reference gasoline stations (French and boundary African country) were also studied. The analysis was done by gas chromatography coupled to a mass spectrometer (GC-MS). The results showed appreciate difference between itinerant and official gasoline samples: ETBE (Ethyl Tert-Butyl Ether) was found in the composition of the French reference but not in the African gasolines composition. Benzene was detected at yields less than 1\% in the French reference gasoline whereas in the gasoline made in the African countries benzene yields were between 2.36 and $4.39 \%$. The ratio of toluene/benzene varied between 1.27 and 10.25 in studied gasoline and was much lower in ambient air. For major components (aromatics and paraffin compounds), we observed another heterogeneity for itinerant gasoline (probably due to numerous hands making and transport).
\end{abstract}

Keywords: ETBE, toluene/benzene ratio, gasoline, motorbike-taxi drivers, Cotonou

\section{Introduction}

All the way from Cotonou, to approximately $3 \mathrm{~km}$ of the international airport Bernardin GANTIN, it is easy to note an exposition to gasoline carboys along the roadside and to observe above the different crossroads, a thick layer of smoke which wraps the population. These gasoline carboys contain unleaded gas coming from Nigeria (Avogbe et al., 2011) and frequently crossing the countryside all the way to Cotonou without taking any precaution.

Nearly $90 \%$ of Cotonou's population gets its supplies of gasoline from these exposed carboys. This preference is due to the low income and the low costs of this gasoline coming from Nigeria, supported by the currencies exchanges on the unofficial market (currently 300 FCFA in 2009 against 490 FCFA in the official stations). This phenomenon is of big concern because it contributes to the deterioration of the environment and a worrying atmospheric pollution.

In such situation, a pilot study has been conducted to examine the quality of the ambient air (Avogbe et al., 2005; Ayi-Fanou et al., 2006). Our results showed that the ambient air in Cotonou contained many air pollutants including volatile organic compounds (VOCs) like benzene and its derivatives, ultrafine particles (UFPs) associated with polycyclic aromatic hydrocarbons (PAHs) at high concentrations. The benzene reaches an average concentration of $76 \mu \mathrm{g} / \mathrm{m}^{3}$, a value higher than the admissible concentration of $5 \mu \mathrm{g} / \mathrm{m}^{3}$ recommended by the WHO; PAHs and UFPs reach $103 \mathrm{ng} / \mathrm{m}^{3}$ and 166816 particles $/ \mathrm{m}^{3}$ respectively, against $1.55 \mathrm{ng} / \mathrm{m}^{3}$ and 5276.5 particles $/ \mathrm{m}^{3}$ in a pilot site located at $80 \mathrm{~km}$ to Cotonou (Sohon village).

Moreover, aren't any petrochemical industries in Benin that use benzene, a product classified as a carcinogenic compound (International Agency for Research on Cancer [IARC], 1974).

At the moment, Benin has adopted the unleaded gas, and new investigations have been led to know the potential 
origin of the pollutants which have been encountered in the air. The main purpose was to know if the gasoline sold in Benin (carboys along the road and official stations) respected the international standard specification with a benzene concentration of $1 \%$ in the gasoline (Kolmetz \& Gentry, 2007) similar to that sold in the developed countries such as France. Indeed, the unleaded gasoline is mainly a mixture of hydrocarbons and oxygenated compounds such as Ethyl Tert-Butyl Ether (ETBE) (Linnekoski, Krause, \& Rihko, 1997; Reich, Cartes, Wisniak, \& Segura, 1999; Vinuesa, Mirabel, \& Ponche, 2003) which increase the octane number of the gasoline (Dagaust, 2007) and reduce the concentrations of aromatic compounds in the mixture (Nadim, Zack, Hoag, \& Liu, 2001). This additive can be added to a total value of $15 \%$ in the gasoline in France. The ethanol seems to decrease the steam pressure of the gasoline, reducing the losses by evaporation (da Silva, Cataluna, de Menezes, Samios, \& Piatnicki, 2005). In contrast, the addition of ethanol in gasoline reduces by $10 \%$ the emission of carbon monoxide (Poulopoulos, Samaras, \& Philippopoulos, 2001). Furthermore, an American study carried out within the framework of American Car/Oil Program showed that the addition of ETBE in the gasoline leads to a reduction in the carbon monoxide emissions (Kivi, Niemi, Nylund, Kuto, \& Orre, 1992; Reuter et al., 1992; Noorman, 1993) and hydrocarbons (Guibet, 1998; de Menezes, Cataluña, Samios, \& da Silva, 2006).

Thus, samples of gasoline were taken in Cotonou from the official stations and carboys along the roadside. The main objective was to determine their composition in benzene and its derivatives and in ETBE and to compare their concentrations to those in French unleaded gasoline label "Sans Plomb 98" and motorbike-taxi drivers (MBTD) exposition followed for few years (Avogbe et al., 2011).

\section{Method}

\subsection{Sampling Campaign}

In August 2009, gasoline samples were taken in Cotonou (Figure 1) and Nigeria. Samples were convoyed for analysis in Dunkirk, France. The samples were selected as follow: one French gasoline from Total France sampled in Dunkirk and thirteen African gasolines originated from Nigeria and Benin. The latter were sampled in official stations (Oryx, Texaco, Total, Sonacop, and Pegaz) and carboys along the roadside (at Vedoko, Opke-oluwa, St Michel, Zongo and red Star site "Place Etoile rouge"). Samples were collected in $2 \mathrm{~mL}$ sealed vials (3 replicates) only one was analysed and referred in the following way: gasoline from France: SP 98, gasoline from Benin: samples 1 to 10 and gasoline from Nigeria: samples 11 to 13 . All the samples were stored in the freezer at $-20^{\circ} \mathrm{C}$ before analysis.

\subsection{Analytical Conditions}

Volatile and semi-volatile hydrocarbons analysis were based on the analytical methods described by Caplain et al. (2006). $1 \mu \mathrm{l}$ of each sample was injected (split ratio of 20:1) in a gas chromatograph (VARIAN 3800) coupled to a mass spectrometer (VARIAN $1200 \mathrm{TQ}$ ). The capillary column is a Factor four VF-5 ms (30 m x $0.25 \mathrm{~mm} \times$ $0.25 \mu \mathrm{m})$ and helium used as carrier gas. The total time for this analysis was $60 \mathrm{mins} ; 40{ }^{\circ} \mathrm{C}$ for $5 \mathrm{mins}, 5^{\circ} \mathrm{C} / \mathrm{min}$ up to $300^{\circ} \mathrm{C}$ and $310^{\circ} \mathrm{C}$ for 3 mins. The parameter of mass detector was impact electronic ion current $=70 \mathrm{eV}$ and temperature of source $280{ }^{\circ} \mathrm{C}$. The samples were analyzed between 40 and 350 mass unit. Benzene and ETBE were identified based on their characteristic ions: $\mathrm{m} / \mathrm{z}=78$ for benzene and $\mathrm{m} / \mathrm{z}=57$ and 89 for ETBE. The total composition of the gasoline was given by using the mode TIC (Total Ion Current).

\subsection{Identification of Compounds}

Compounds were identified by comparing retention times of chromatographic peaks from gasoline samples with those from standard mixtures and by comparing mass spectra with those contained in NIST and/or WILEY libraries. The percentage of each compound was determined using TIC surface areas.

\subsection{Study of the Exposure of Motorbike-Taxi Drivers to Benzene and Toluene}

Benzene and toluene ambient concentrations of personal exposure were determined by using Radiello diffusive samplers consisting of an active carbon cartridge enclosed in a porous polyethylene body (Fondazione Salvatore Maugeri, Paduva Italy). The Radiello tube has an uptake of $80 \mathrm{~m}^{3}$ per min at $25^{\circ} \mathrm{C}$ and $1 \mathrm{~atm}$. Benzene, toluene, ETBE, paraffin and aromatic compounds were analysed by GC-MS using the method described by Sørensen, Skov, Autrup, Hertel, and Loft (2003). The ratio of toluene/benzene was used to evaluate the variability and origin of fuel (Guo, Lee, Louie, \& Ho, 2004). 


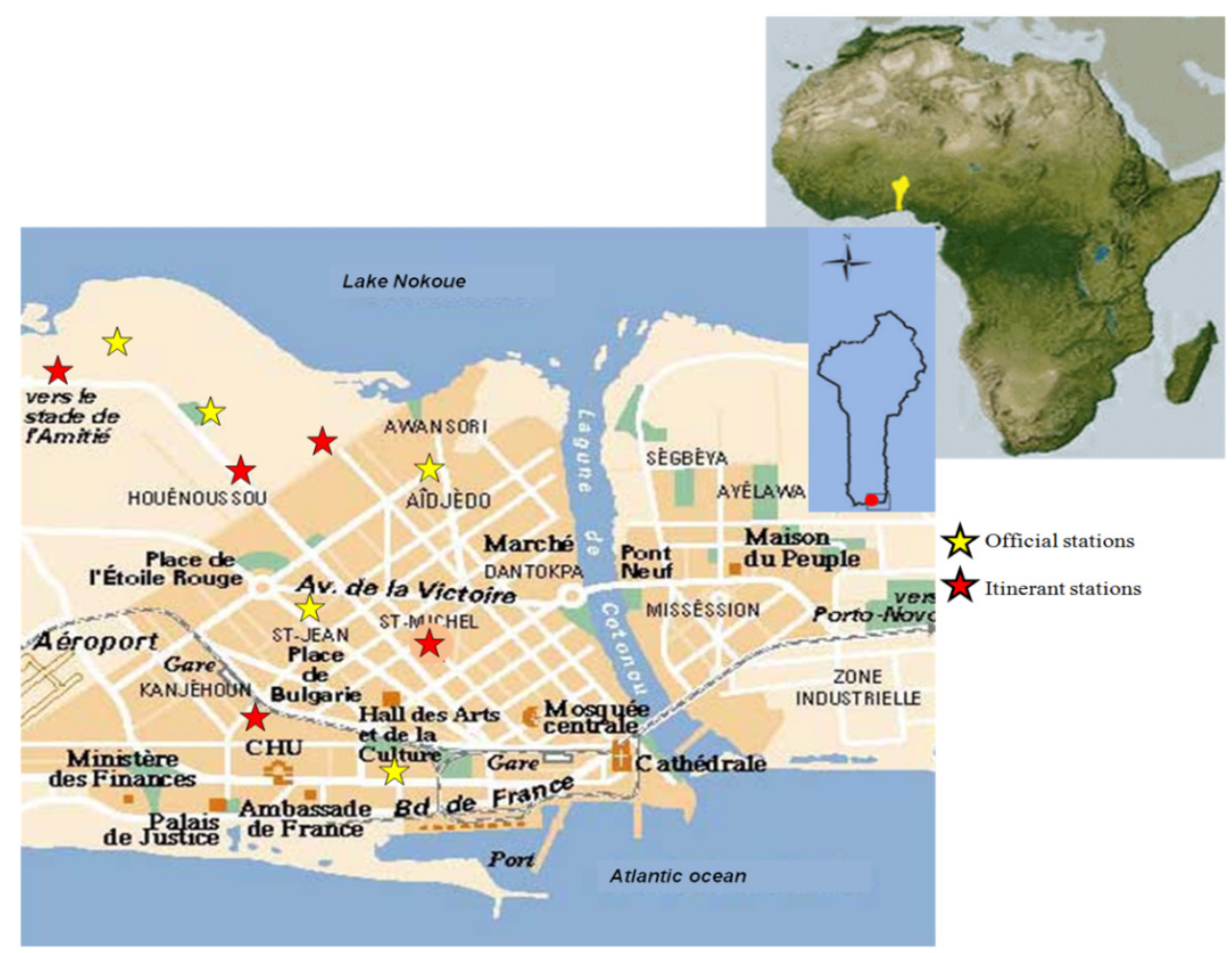

Figure 1. Geographical location of the sampling site in Cotonou

\section{Results and Discussion}

Alkyl-lead compounds are replaced by oxygenated compounds which have become increasingly important components in automotive gasoline, thus improving octane rating (Nadim et al., 2001) and reducing the emission of carbon monoxide (de Menezes et al., 2006). One of the most widely used oxygenated compounds in gasoline is ETBE (van Wezel, Puijker, Vink, Versteegh, \& de Voogt, 2009). We will show in this section the main results of gasoline compositions (Benzene, toluene, ETBE, paraffin and aromatics) present in gasoline using by motorbike-taxi drivers of Cotonou. The Table 1 show the compositions of gasoline (benzene, ETBE) determined by GC-MS analysis.

Table 1. Benzene and ETBE amounts (percent) in the samples of examined gasoline

\begin{tabular}{lccccc}
\hline & Sample & Benzene & Median & Mean \pm SD & ETBE \\
\hline SP 98 & SuperPlus & 0.69 & & & 13.68 \\
Official stations & 2 & 4.15 & 3.58 & $3.44 \pm 0.91$ & n.d.* \\
Benin & 3 & 2.92 & & & n.d.* \\
& 6 & 3.58 & & & n.d.* \\
& 8 & 2.18 & & & n.d.* \\
& 10 & 4.39 & & & 0.75 \\
Official stations & 11 & 2.36 & 3.16 & $3.21 \pm 0.87$ & n.d.* \\
Nigeria & 12 & 4.10 & & & n.d.* \\
& 13 & 3.16 & & & n.d.* \\
Itinerant stations & 1 & 1.98 & 2.84 & $2.81 \pm 0.64$ & 0.29 \\
& 4 & 2.84 & & & n.d.* \\
& 5 & 3.19 & & & n.d.* \\
& 7 & 3.63 & & & n.d.* \\
& 9 & 2.42 & & & 0.65 \\
\hline
\end{tabular}

*n.d.: not detected 
For these studied gasoline, we can see that the compositions of all thirteen samples are relatively similar for gasoline originating from both official stations and itinerant stations (African stations). ETBE are not detected in all samples except Pegaz of official stations, Vedoko and Etoile of itinerant stations who have respectively 0.75, 0.29 and $0.65 \%$ of ETBE whereas it was $13.68 \%$ in SP 98 of France. According to french regulations, ETBE concentration in gasoline can reach 15\% (Norme NF EN 228, 2008). Westphal, Krahl, Brüning, Hallier, and Bünger (2010) and Kim, O'Shea \& Cooper (2012) had similar results. There was no difference concerning the percentage of benzene in all examined gasolines. Official and itinerant stations showed a remarkably higher percentage of benzene. The highest percentage $(4.39 \%)$ was observed in official stations whereas in SP 98 it was less $1 \%$ either three to six times as high as french unleaded gasoline. The benzene concentration level in the gasoline is $1 \%$ in international standard specification (Kolmetz \& Gentry, 2007). Some studies showed that the gasolines respect this regulation (Simon et al., 2004; Adami et al., 2006; Bonfim, Alves, \& Filho, 2012). Table 2 lists some average ETBE, aromatic compounds, paraffin and ratio of toluene/benzene for various countries.

Table 2. Summary of average ETBE, aromatic compounds, paraffin and ratio of toluene/benzene in gasoline for different countries

\begin{tabular}{lcccccl}
\hline Cities/Countries & ETBE & Aromatics & Paraffin & Ratio T/B & Benzene & \multicolumn{1}{c}{ Reference } \\
\hline Germany & $10 \%$ & - & - & - & - & Westphal et al., 2010 \\
USA & $15.7 \%$ & - & - & - & - & Kim et al., 2012 \\
Italy & - & $29.02-41.77 \%$ & $36.68-44.75 \%$ & $6.59-15.54$ & $0.39-1.06 \%$ & Adami et al., 2006 \\
Brazil & - & - & - & - & $0.30-0.60 \%$ & Bonfim et al., 2012 \\
Brazil (Sao Paulo) & - & - & - & 1.68 & $16.7 \mu \mathrm{g} / \mathrm{m}^{3}$ & Gee et al., 1998 \\
Chile (Santiago) & - & - & - & 2.01 & $14.8 \mu \mathrm{g} / \mathrm{m}^{3}$ & Gee et al., 1998 \\
Chine (Hong Kong) & - & - & - & 7.07 & $10.05 \mu \mathrm{g} / \mathrm{m}^{3}$ & Lee et al., 2002 \\
Spain & - & $-64 \%$ & - & - & - & Montells et al., 2000 \\
Scotland & - & $-30.5 \%$ & - & - & - & Sentenac et al., 2012 \\
Brazil & - & $26.90-38.50 \%$ & $10.10-13.70 \%$ & - & - & de Menezes et al., 2006 \\
USA (Atlanta) & - & - & - & 5.14 & $0.55 \%$ & NESCAUM, 1995 \\
USA & - & - & - & 3.56 & $11.50 \mathrm{mg} / \mathrm{mL}$ & Kaplan et al., 1997 \\
Brazil & - & - & - & 3.33 & $30 \mathrm{~g} / \mathrm{L}$ & Montells et al., 2000 \\
\hline
\end{tabular}

(-) not available

ETBE is also used in gasoline formulation to decrease the concentration of aromatics (Pumphrey, Brand, \& Scheller, 2000; Nadim et al., 2001). 
Table 3 shows trends of paraffin and aromatic hydrocarbons found in all three types of gasolines.

Table 3. Values (percent) of paraffin and aromatic hydrocarbons in the three types of gasoline

\begin{tabular}{lcccccc}
\hline & Paraffin & Median & Mean \pm SD & Aromatic & Median & Mean \pm SD \\
\hline SP 98 & 5.41 & & & 44.70 & & \\
Official stations & 5.07 & 5.57 & $5.57 \pm 0.46$ & 39.91 & 44.26 & $43.92 \pm 3.87$ \\
Benin & 6.25 & & & 40.14 & & \\
& 5.57 & & & 48.51 & & \\
& 5.23 & & & 46.80 & & \\
& 5.71 & & & 44.26 & & \\
Official stations & 6.15 & 2.37 & $3.62 \pm 2.19$ & 51.51 & 51.56 & $51.68 \pm 0.26$ \\
Nigeria & 2.34 & & & 51.56 & & \\
& 2.37 & & & 51.98 & & \\
Itinerant stations & 8.54 & 6.88 & $5.91 \pm 2.26$ & 39.40 & 41.39 & $41.12 \pm 2.18$ \\
& 6.88 & & & 41.39 & & \\
& 7.04 & & & 41.49 & & \\
& 3.75 & & & 38.91 & & \\
& 3.32 & & & 44.42 & & \\
\hline
\end{tabular}

In this study, total concentration of aromatics was equivalent in studied gasoline (Mean: 41.12 to $51.68 \%$ ). These concentrations were lower than the aromatics level in unleaded gasoline in Spain (Montells, Aceves, \& Grimalt, 2000) and higher than the level in Scotland (Sentenac, Ayeni, \& Lynch, 2012), Brazil (de Menezes et al., 2006) and Italy (Adami et al., 2006) (Table 2). This high level of aromatics in examined gasolines could be probably due to the weak rate of ETBE. Furthermore the total paraffin values of official stations of Benin ranged from 5.71 to $6.25 \%$ against 3.32 to $8.54 \%$ for itinerant stations and 2.34 to $6.15 \%$ for official stations of the border between Benin and Nigeria. French unleaded gasoline showed 5.41 percent of paraffin. These concentrations of paraffin were lower than those reported in Brazil (de Menezes et al., 2006) and Italy (Adami et al., 2006). The means and medians obtained show a better homogeneity resulting from the three types of gasoline as well as for total paraffin and total aromatic hydrocarbons. Some authors used concentration ratios of toluene/benzene in order to evaluate different types of fuel and rate of diesel or gasoline vehicles driven in different urban sectors (Guo et al., 2004). 
Table 4 present toluene/benzene ratio in examined gasoline.

Table 4. Ratio of toluene and benzene in the three types of gasoline

\begin{tabular}{lcccc}
\hline & Benzene (\%) & Toluene (\%) & Toluene/benzene & Mean \pm SD \\
\hline SP 98 & 0.69 & 7.03 & 10.25 & \\
Official stations & 4.39 & 5.59 & 1.27 & $2.76 \pm 1.38$ \\
Benin & 4.15 & 6.30 & 1.52 & \\
& 2.92 & 11.38 & 3.89 & \\
& 3.58 & 9.79 & 2.74 & \\
& 2.18 & 9.56 & 4.38 & \\
Official stations & 2.36 & 6.44 & 2.73 & $2.83 \pm 0.26$ \\
Nigeria & 4.10 & 10.83 & 2.64 & \\
& 3.16 & 9.88 & 3.13 & \\
Itinerant stations & 1.98 & 11.45 & 5.77 & $3.76 \pm 1.30$ \\
& 2.84 & 12.02 & 4.24 & \\
& 3.19 & 10.42 & 3.27 & \\
& 3.63 & 8.84 & 2.43 & \\
& 2.42 & 7.51 & 3.10 & \\
\hline
\end{tabular}

The mean toluene/benzene (T/B) ratio of unleaded gasolines of official stations in Benin, Nigeria and itirenant stations were respectively $2.76,2.83$ and 3.76 (Table 4). These results showed a similarity between these different stations. The toluene/benzene ratio in gasoline is in the order of 9 (Institut National de l'Environnement Industriel et des Risques [INERIS], 2010). This ratio was 10.25 in unleaded gasoline SP98 of France. On the other hand the value of this ratio was low in Atlanta city (5.14 while considering percent of toluene and benzene, Northeast States for Coordinated Air Use Management [NESCAUM], 1995), USA (3.56 while considering average $(\mathrm{mg} / \mathrm{mL})$ of toluene and benzene, Kaplan, Galperin, Lu, \& Lee, 1997) and Brazil (3.33 while considering concentration $(\mathrm{g} / \mathrm{L})$ of toluene and benzene, Montelles et al., 2000). This ratio varied from 6.59 to 15.54 in examined gasoline in Italy considering the percentage of toluene and benzene (Adami et al., 2006). The values obtained in this study vary from 2.76 to 3.76 . The differences observed between values obtained in African and developed countries may be due to differences in the composition of gasoline and/or concentration of compounds. The results showed a low ratio of toluene/benzene in sampled gasolines which indicates a high concentration of benzene in gasolines.

The main source of benzene and toluene is vehicle exhaust gases and Lee, Chiu, Ho, Zou, and Wang (2002) described that the ratio of toluene/benzene increases with traffic. Meuwese-Mulder (2006) show clearly that at remote urban sites ratios of toluene to benzene are often below 1, the well-known standard values ranging from 3 to 5 corresponding to a city's background. This result is also confirmed by the paper of Gelencsér, Siszler, and Hlavay (1997), where the ratio of toluene/benzene was used as a tool for charactezing the distance from vehicles emission sources (1 to 1.5). For Xu, Pereira, Miller, Grgicak-Mannion, and Wheeler (2010), benzene is predominantly emitted from traffic whereas toluene is generated from both traffic and solvents. The ratio between toluene and benzene (T/B) can act as an indicator of traffic emissions when this ratio is within the range of 1.5 to 4.3 as repeated by previous studies (Hoque, Khillare, Agarwal, Shridhar, \& Balachandran, 2008; Liu et al., 2009). For ratios $>4.3$ solvent source compounds likely. For fresh plumes ratio of toluene/benzene was 2 to 2.4 and aged to $<1$ (Bahreini et al., 2012). In this study, the results of personal exposure monitoring are presented in Table 5 . 
Table 5. Summary of personal exposure monitoring for one-week

\begin{tabular}{lrrrrrr}
\hline \multirow{2}{*}{ Compounds } & \multicolumn{6}{c}{ motorbike-taxi drivers } \\
\cline { 2 - 7 } & 1 & 2 & 3 & 4 & 5 & Mean $\pm \mathrm{SD}$ \\
\hline Benzene $\left(\mu \mathrm{g} / \mathrm{m}^{3}\right)$ & 14.05 & 4.65 & 24.57 & 44.79 & 87.27 & 35.07 \\
Toluene $\left(\mu \mathrm{g} / \mathrm{m}^{3}\right)$ & 0.82 & 3.34 & 5.51 & 2.90 & 2.86 & 3.09 \\
Ratio T/B & 0.06 & 0.72 & 0.22 & 0.06 & 0.03 & 0.22 \\
\hline
\end{tabular}

The benzene concentration of MBTD over one-week average exposure was more ten times as high as toluene concentration. Therefore the ratio of $\mathrm{T} / \mathrm{B}$ was between 0.03 and 0.72 . These results indicated much lower ratio of T/B within MBTD. This ratio in air is in the order of 5 (INERIS, 2010). In Toulouse City, Simon et al. (2004) have found ratio of T/B equal to 5.54, 2.90 to $3.40,2.20,3.80$ to 4.40, 8.60, and up to 10 were observed in Paris (Vardoulakis, Gonzalez-Flesca, \& Fisher, 2002), Copenhagen (Hansen \& Palmgren, 1996), Mortsel (Buczynska et al., 2009), Ren-Wu (Hsieh, Yang, \& Chen, 2006), Hong Kong (Lee et al., 2002), respectively. Buczynska et al. (2009) suggested the same common source (traffic exhausts) of toluene and benzene as an explanation for such low values of T/B ratio. In this work, this ratio was much smaller because of high benzene concentration level (Mean: $35 \mu \mathrm{g} / \mathrm{m}^{3}$ ). Benzene concentration in Cotonou ambient air was seven times as high as the European limit value $\left(5 \mu \mathrm{g} / \mathrm{m}^{3}\right)$. It suggests the existence of other sources than traffic exhausts which could result using itinerant gasoline along the roadside and different crossroads. This could be the proof of an excessive manipulation of gasoline (successive transfer and/or evaporations).

In conclusion, Benin unleaded gasolines doesn't contain ETBE which increase the octane number of the gasoline (Dagaust, 2007) what promote a reduction of concentrations of aromatics (Nadim et al., 2001), carbon monoxide emissions (Noorman, 1993) and hydrocarbons (de Menezes et al., 2006). Moreover, benzene is found in high level in the gasoline. The same conclusions have been found in the gasoline of the border Benin-Nigeria. It confirms that Benin gets a stock in gasoline to Nigeria neighboring country. These results demonstrate that the ambient air in Cotonou contains high levels of benzene, carcinogenic compound by IARC (1974) which come as well as traffic exhaust that gasoline.

\section{References}

Adami, G., Larese, F., Venier, M., Barbieri, P., Lo Coco, F., \& Reisenhofer, E. (2006). Penetration of benzene, toluene and xylenes contained in gasolines through human abdominal skin in vitro. Toxicology in Vitro, 20(8), 1321-1330. http://dx.doi.org/10.1016/j.tiv.2006.05.008

Avogbe, P. H., Ayi-Fanou, L., Autrup, H., Loft, S., Fayomi, B., Sanni, A., ... Møller, P. (2005). Ultrafine particulate matter and high-level benzene urban air pollution in relation to oxidative DNA damage. Carcinogenesis, 26, 613-620. http://dx.doi.org/10.1093/carcin/bgh353

Avogbe, P. H., Ayi-Fanou, L., Cachon, B., Chabi, N., Debende, A., Dewaele, D., ... Sanni, A. (2011). Hematological changes among Beninese motor-bike taxi drivers exposed to benzene by urban air pollution. African Journal of Environmental Science and Technology, 5(6), 464-472.

Ayi Fanou, L., Mobio, T. A., Creppy, E. E., Fayomi, B., Fustoni, S., Møller, P., ... Autrup, H. (2006). Survey of air pollution in Cotonou, Benin - air monitoring and biomarkers. Science Total Environment, 358(1-3), 85-96. http://dx.doi.org/10.1016/j.scitotenv.2005.03.025

Bahreini, R., Middlebrook, A. M., Gouw, J. A. de, Warneke, C., Trainer, M., Brock, C. A., ... Parrish, D. D. (2012). Gasoline emissions dominate over diesel in formation of secondary organic aerosol mass. Geophysical Research Letters, 39, L06805. http://dx.doi.org/10.1029/2011GL050718

Bonfim, R. R., Alves, I. R. M., \& Filho, N. R. A. (2012). Fast-HRGC method for quantitative determination of benzene in gasoline. Fuel, 99, 165-169. http://dx.doi.org/10.1016/j.fuel.2012.04.027

Buczynska, A. J., Krata, A., Stranger, M., Godoi, A. F. L., Kontozova-Deutsch, V., Bencs, ... Grieken, R. V. (2009). Atmospheric BTEX-concentrations in an area with intensive street traffic. Atmospheric Environment, 43(2), 311-318. http://dx.doi.org/10.1016/j.atmosenv.2008.09.071 
Caplain, I., Cazier, F., Nouali, H., Mercier, A., Déchaux, J. C., Nollet, V., ... Vidon, R. (2006). Emissions of unregulated pollutants from European gasoline and diesel passenger cars. Atmospheric Environment, 40, 5954-5966. http://dx.doi.org/10.1016/j.atmosenv.2005.12.049

Da Silva, R., Cataluna, R., de Menezes, E. W., Samios, D., \& Piatnicki, C. M. S. (2005). Effect of additives on the antiknock properties and Reid vapor pressure of gasoline. Gasoline, 84, 951-959. http://dx.doi.org/10.1016/j.fuel.2005.01.008

Dagaust, P. (2007). Influence of MTBE and ETBE on the emission of exhaust gases. Third European combustion meeting ECM. Retrieved from http://www.combustion.org.uk/ECM_2007/ecm2007_papers/2-12.pdf

De Menezes, E. W., Cataluña, R., Samios, D., \& da Silva, R. (2006). Addition of an azeotropic ETBE/ethanol $\begin{array}{lllll}\text { mixture in eurosuper-type gasolines. } & \text { Fuel, }\end{array}$ http://dx.doi.org/10.1016/j.fuel.2006.04.014

Gelencsér, A., Siszler, K., \& Hlavay, J. (1997). Toluene-Benzene Concentration Ratio as a Tool for Characterizing the Distance from Vehicular Emission Sources. Environmental Science \& Technology, 31, 2869-2872. http://dx.doi.org/10.1021/es970004c

Guibet, J. C. (1998). Carburants liquides. Techniques de l'ingenieur, Génie énergétique 3, n BE8545 (s. d.): BE8545.1-BE8545.31.

Guo, H., Lee, S. C., Louie, P. K. K., \& Ho, K. F. (2004). Characterization of hydrocarbons, halocarbons and carbonyls in the atmosphere of Hong Kong. Chemosphere, 57, 1363-1372. http://dx.doi.org/10.1016/j.chemosphere.2004.07.055

Hansen, A. B., \& Palmgren, F. (1996). VOC air pollutants in Copenhagen. The Science of the Total Environment, 189-190, 451-457. http://dx.doi.org/10.1016/0048-9697(96)05245-X

Hoque, R. R., Khillare, P. S., Agarwal, T., Shridhar, V., \& Balachandran, S. (2008). Spatial and temporal variation of BTEX in the urban atmosphere of Delhi, India. Science of the Total Environment, 392, 30-40. http://dx.doi.org/10.1016/j.scitotenv.2007.08.036

Hsieh, L. T., Yang, H. H., \& Chen, H. W. (2006). Ambient BTEX and MTBE in the neighborhoods of different industrial parks in Southern Taiwan. Journal of Hazardous Materials, 128(2-3), 106-115. http://dx.doi.org/10.1016/j.jhazmat.2005.08.001

Institut National de l'Environnement Industriel et des Risques. (2010). Impact local des stations-service sur les concentrations de benzène dans l'environnement (air intérieur et extérieur)-Etude exploratoire sur deux sites parisiens. Retrieved from http://www.ineris.fr/.../drc-09-104235-03943a-final-def-en-ligne.pdf

International Agency for Research on Cancer. (1974). Benzene. IARC Monographs on the Evaluation of Carcinogenic Risk of Chemicals to Man. International Agency for Research on Cancer (vol. 7, pp. 203-221). Lyon, France.

Kaplan, I. R., Galperin, Y., Lu, S. T., \& Lee, R. P. (1997). Forensic Environmental Geochemistry: differentiation of fuel-types, their sources and release time. Organic Geochemistry, 27(5-6), 289-299, 301-317. http://dx.doi.org/10.1016/S0146-6380(97)87941-7

Kim, D. K., O'Shea, K. E., \& Cooper, W. J. (2012). Oxidative degradation of alternative gasoline oxygenates in aqueous solution by ultrasonic irradiation: Mechanistic study. Science of the Total Environment, 430, 246-259. http://dx.doi.org/10.1016/j.scitotenv.2011.09.016

Kivi, J., Niemi, A., Nylund, N. O., Kuto, M., \& Orre, K. (1992). Use of MTBE and ETBE as gasoline reformulation components. SAE Technical Paper, 922379, 1-17. http://dx.doi.org/10.4271/922379

Kolmetz, K., \& Gentry, J. C. (2007). Guidelines for BTX Revamps, AIChE Spring Conference.

Lee, S. C., Chiu, M. Y., Ho, K. F., Zou, S. C., \& Wang, X. M. (2002). Volatile organic compounds (VOCs) in urban atmosphere of Hong Kong. Chemosphere, 48, 375-382. http://dx.doi.org/10.1016/S0045-6535(02)00040-1

Linnekoski, J. A., Krause, A. O., \& Rihko, L. K. (1997). Kinetics of heterogeneously catalysed formation of tert-amyl ethyl ether. Industrial \& Engineering Chemistry Research, 36, 310-316. http://dx.doi.org/10.1021/ie960251+ 
Liu, J., Mu, Y., Zhang, Y., Zhang, Z., Wang, X., Liu, Y., \& Sun, Z. (2009). Atmospheric levels of BTEX compounds during the 2008 Olympic Games in the urban area of Beijing. Science of the Total Environment, 408, 109-116. http://dx.doi.org/10.1016/j.scitotenv.2009.09.026

Meuwese-Mulder, T. (2006). The ratio of benzene and toluene in measurements of a background urban site at different weather conditions. Groningen, NL, Synspec. Retrieved from http://www.synspec.nl/pdf/Ratio_of_B-T.pdf

Montells, R., Aceves, M., \& Grimalt, J. O. (2000). Sampling and analysis of volatile organic compounds emitted from leaded and unleaded gasoline powered motor vehicles. Environmental Monitoring and Assessment, 62, 1-14. http://dx.doi.org/10.1023/A:1006201100174

Nadim, F., Zack, P., Hoag, G. E., \& Liu, S. (2001). United States experience with gasoline additives. Energy Policy, 29, 1-5. http://dx.doi.org/10.1016/S0301-4215(00)00099-9

Noorman, M. T. (1993). The effect of MTBE, DIPE and TAME on vehicle emissions. SAE Technical Paper, 932668. http://dx.doi.org/10.4271/932668

Norme NF EN 228 (2008, November). Carburants pour automobiles-Essence sans plomb-Exigences et methodes d'essai.

Northeast States for Coordinated Air Use Management. (1995). Preview of the 1994 ozone precursor concentrations in the northeastern U.S. 5/1/94 draft report prepared by the Ambient Monitoring and Assessment Committee of the Northeast States for Coordinated Air Use Management, Boston, MA.

Poulopoulos, S. G., Samaras, D. P., \& Philippopoulos, C. J. (2001). Regulated and unregulated from an internal combustion engine operating on ethanolcontaining gasolines. Atmospheric Environment, 35, 4399-4406. http://dx.doi.org/10.1016/S1352-2310(01)00248-5

Pumphrey, J. A., Brand, J. I., \& Scheller, W. A. (2000). Vapour pressure measurements and predictions for alcohols-gasoline blends. Fuel, 79, 1405-1411. http://dx.doi.org/10.1016/S0016-2361(99)00284-7

Reich, R., Cartes, M., Wisniak, J., \& Segura, H. (1999). Phase equilibria in the ternary system hexane+ethyl 1,1-dimethylethyl ether+heptane. Fluid Phase Equilibria 154, 99-108. http://dx.doi.org/10.1016/S0378-3812(98)00420-8

Reuter, R. M., Benson, J. D., Burns, V., Gorse, R., Hochhausser, A. M., Koelh, W., ... Rutherford, J. (1992). Effects of oxygenated gasolines and RVP on automotive emission. Auto-oil improvement program. SAE Technical Paper, 920326. http://dx.doi.org/10.4271/920326

Sentenac, P., Ayeni, S., \& Lynch, R. J. (2012). Effects of gasoline and diesel additives on kaolinite. Environment Earth Science, 66, 783-792. http://dx.doi.org/10.1007/s12665-011-1287-2

Simon, V., Baer, M., Torres, L., Olivier, S., Meybeck, M., \& Massa, J. P. D. (2004). The impact of reduction in the benzene limit value in gasoline on airborne benzene, toluene and xylenes levels. Science of The Total Environment, 334-335, 177-183. http://dx.doi.org/10.1016/j.scitotenv.2004.04.065

Sørensen, M., Skov, H., Autrup, H., Hertel, O., \& Loft, S. (2003). Urban benzene exposure and oxidative DNA damage : influence of genetic polymorphisms in metabolism genes. Science Total Environment, 309, 69-80. http://dx.doi.org/10.1016/S0048-9697(03)00054-8

Van Wezel, A., Puijker, L., Vink, C., Versteegh, A., \& de Voogt, P. (2009). Odour and flavour thresholds of gasoline additives (MTBE, ETBE and TAME) and their occurrence in Dutch drinking water collection areas. Chemosphere, 76(5), 672-676. http://dx.doi.org/10.1016/j.chemosphere.2009.03.073

Vardoulakis, S., Gonzalez-Flesca, N., \& Fisher, B. E. A. (2002). Assessment of trafficrelated air pollution in two street canyons in Paris: Implications for exposure studies. Atmospheric Environment, 36, 1025-1039. http://dx.doi.org/10.1016/S1352-2310(01)00288-6

Vinuesa, J. F., Mirabel, P., \& Ponche, J. L. (2003). Air quality effects of using reformulated and oxygenated gasoline gasoline blends: application to the Strasbourg area (F). Atmospheric Environment, 37, 1757-1774. http://dx.doi.org/10.1016/S1352-2310(03)00067-0

Westphal, G. A., Krahl, J., Brüning, T., Hallier, E., \& Bünger, J. (2010). Ether oxygenate additives in gasoline reduce toxicity of exhausts. Toxicology, 268, 198-203. http://dx.doi.org/10.1016/j.tox.2009.12.016 
Xu, X., Pereira, M., Miller, L. J., Grgicak-Mannion, A., \& Wheeler, A. (2010). Methods used to detect additional sources using Toluene/Benzene in Windsor, Ontario (2004-2006). American Geophysical Union Fall Meeting Abstracts \#A33E-0217. 